University of Nebraska - Lincoln

DigitalCommons@University of Nebraska - Lincoln

Agronomy \& Horticulture -- Faculty Publications

Agronomy and Horticulture Department

1922

\title{
Relation of Hardpan to Root Penetration in the Great Plains
}

\author{
J. E. Weaver \\ University of Nebraska-Lincoln \\ John Crist \\ University of Nebraska-Lincoln
}

Follow this and additional works at: https://digitalcommons.unl.edu/agronomyfacpub

Part of the Plant Sciences Commons

Weaver, J. E. and Crist, John, "Relation of Hardpan to Root Penetration in the Great Plains" (1922). Agronomy \& Horticulture -- Faculty Publications. 440.

https://digitalcommons.unl.edu/agronomyfacpub/440

This Article is brought to you for free and open access by the Agronomy and Horticulture Department at DigitalCommons@University of Nebraska - Lincoln. It has been accepted for inclusion in Agronomy \& Horticulture -Faculty Publications by an authorized administrator of DigitalCommons@University of Nebraska - Lincoln. 


\title{
RELATION OF HARDPAN TO ROOT PENETRATION IN THE GREAT PLAINS
}

\author{
J. E. Weaver and John W. Crist \\ University of Nebraska
}

During the excavation of root systems of native and crop plants throughout the Great Plains region during the past five years (Weaver, 1919, I920, I922) contact has been made in more than thirty fields with the so-called hardpan. Such a layer of soil underlies much of this area of low rainfall, at depths varying from 15 inches to 3 feet. It varies from 8 inches to over I.5 feet in thickness. In connection with studies on the physical and chemical composition of the soils and their seasonal water-content under natural and cropped conditions, a more detailed study has been made of the soil in this hardened layer. The major portion of this work was done at Burlington, Colorado, a station selected as being typically representative of High Plains conditions, but analyses of hardpan from Flagler, Colorado, and Colby, Kansas, were also made.

\section{The Hardpan}

Mechanical and chemical analyses of the soils at Burlington are given in Tables I and 2. These represent the several foot sections to a depth of six feet, except in the first foot, where samples were taken to depths of six and twelve inches, respectively. The samples from Flagler and Colby were obtained from the hardpan layer at depths of approximately I.3 to 2.I and I.9 to 2.6 feet, respectively. At Flagler the field had been broken only one year, at Colby for a number of years. The cropped area at Burlington was on land broken only 3 years. Here a well-formed hardpan occurred at a depth of about 2 feet. The change in soil structure was quite distinct, the harder layer continuing to a depth of 4 feet, where it gave way to a loess-like soil very loose and powdery in structure. Hence in Tables I and 2 the first three samples are of soil above the hardpan, the next two in the hardpan, while the last two are from the soil below it.

An examination of Tables $I$ and 2 shows that the hardpan at Flagler and also that at Colby appears to be due solely to the calcareous nature of the soil. The former contains a relatively low percentage of clay and at the same time more inorganic carbonate along with calcium oxide than any one of the Burlington samples. The Colby sample is higher in clay content, but holds nearly twice the amount of carbonate compounds. At Burlington the case is different. Here calcareousness alone does not account for the condition. A1though the carbonates increase with depth, they do not reach a concentration sufficient to bring about the hardening of the soil, unless their effect is supple- 
mented by other agencies. Furthermore, the carbonates are more abundant below the hardpan than in it.

TABLE I. Mechanical analyses and moisture constants of soils

\begin{tabular}{|c|c|c|c|c|c|c|c|c|c|c|c|}
\hline $\begin{array}{l}\text { Burlington, } \\
\text { Colo. }\end{array}$ & 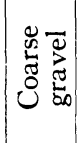 & 运 & 总泀 & 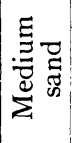 & 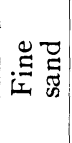 & 完怘焉 & 胥苛 & $\stackrel{\Xi}{\tilde{n}}$ & 苞 & 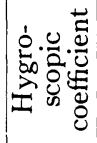 & 莺 \\
\hline Feet & & & & & & & & & & & \\
\hline $\begin{array}{l}0.0 \text { to } 0.5 \\
0.5 \text { to } 1.0\end{array}$ & $\begin{array}{l}0.0 \\
0.0\end{array}$ & $\begin{array}{l}0.0 \\
0.0\end{array}$ & $\begin{array}{l}0.0 \\
0.0\end{array}$ & $\begin{array}{l}0.2 \\
0.2\end{array}$ & $\begin{array}{l}2.5 \\
2.1\end{array}$ & $\begin{array}{l}48.6 \\
49.1\end{array}$ & $\begin{array}{l}5 \mathrm{I} \cdot 3 \\
5 \mathrm{I} \cdot 4\end{array}$ & $\begin{array}{l}33 \cdot 4 \\
32.5\end{array}$ & $\begin{array}{l}\text { I } 5.3 \\
\text { I6.I }\end{array}$ & $\begin{array}{l}10.7 \\
10.8\end{array}$ & $\begin{array}{l}24.9 \\
25.2\end{array}$ \\
\hline I to 2 & 0.0 & 0.0 & 0.0 & 0.2 & I. 8 & 46.7 & 48.7 & 32.0 & I9.3 & I I. 6 & 26.6 \\
\hline 2 to 3 & 0.0 & 0.0 & 0.0 & 0.1 & I. 5 & 45.5 & $47 . \mathrm{I}$ & 31.0 & 21.9 & I2.I & 27.3 \\
\hline 3 to 4 & 0.0 & 0.0 & 0.0 & O.I & 0.9 & 42.2 & 43.2 & 34.1 & 22.7 & 12.0 & 28.2 \\
\hline 4 to 5 & 0.0 & 0.0 & 0.0 & $0 . I$ & 0.8 & $5^{2.6}$ & 53.5 & 31.3 & 15.2 & 10.9 & 24.1 \\
\hline 5 to 6 & 0.0 & 0.0 & 0.0 & 0.0 & I.O & 56.8 & 57.8 & 28.8 & I 3.4 & I0.0 & $22 . \mathrm{I}$ \\
\hline Flagler, Co & 0.0 & 0.0 & 0.0 & O.I & 0.9 & $44 \cdot 3$ & $45 \cdot 3$ & $40 . I$ & I 4.6 & I0.9 & 27.6 \\
\hline & 0.0 & 0.0 & 4.0 & 2.7 & 3.4 & 38.1 & 48.2 & 29.6 & 22.2 & I0.2 & 25.0 \\
\hline
\end{tabular}

TABLE 2. Chemical analyses of soils (total)

\begin{tabular}{|c|c|c|c|c|c|c|c|c|c|c|}
\hline $\begin{array}{l}\text { Burlington, } \\
\text { Colo. }\end{array}$ & $\stackrel{0}{\text { ก๊ }}$ & 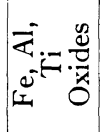 & i & $\sum_{i=1}^{0}$ & O̊ & $0^{\infty}$ & 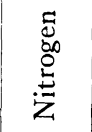 & 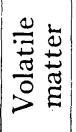 & 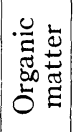 & 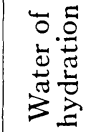 \\
\hline $\begin{array}{l}\text { Feet } \\
\text { O.o to } 0.5 \\
0.5 \text { to } 1.0 \\
\text { I to } 2 \\
2 \text { to } 3 \\
3 \text { to } 4 \\
4 \text { to } 5 \\
5 \text { to } 6\end{array}$ & $\begin{array}{l}\cdots \cdots \\
\cdots \cdots \\
\cdots \cdots \\
69.26 \\
66.68 \\
67.29\end{array}$ & $\begin{array}{l}\text { I6.25 } \\
\text { I6.48 } \\
\text { I 5.39 }\end{array}$ & $\begin{array}{l}\mathbf{5 . 3 0} \\
\mathbf{5} \cdot \mathbf{5} \mathrm{I} \\
\mathbf{5} \cdot 48\end{array}$ & $\begin{array}{l}0.88 \\
0.92 \\
0.91\end{array}$ & $\begin{array}{l}0.03 \\
0.30 \\
1.7 \mathrm{I} \\
2.09 \\
2.59 \\
2.99 \\
3.28\end{array}$ & $\begin{array}{l}0.189 \\
0.504 \\
0.428 \\
0.406 \\
0.525 \\
0.169 \\
0.161\end{array}$ & \begin{tabular}{|l|}
0.184 \\
0.130 \\
0.101 \\
0.086 \\
0.084 \\
0.041 \\
0.032
\end{tabular} & $\begin{array}{l}4.67 \\
3.13 \\
3.11 \\
3.34 \\
2.84 \\
\text { I.60 } \\
\text { I.1 } 4\end{array}$ & \begin{tabular}{|l|}
3.14 \\
2.05 \\
1.56 \\
1.58 \\
$1.4 I$ \\
0.50 \\
0.45
\end{tabular} & $\begin{array}{l}1.53 \\
1.08 \\
1.55 \\
1.76 \\
1.43 \\
1.10 \\
0.69\end{array}$ \\
\hline $\begin{array}{l}\text { Flagler, Colo. } \\
\text { Colby, Kans. . }\end{array}$ & $\begin{array}{l}66.64 \\
66.22\end{array}$ & $\begin{array}{l}\text { I } 5.98 \\
\text { I } 3.70\end{array}$ & $\begin{array}{l}5.97 \\
9.60\end{array}$ & $\begin{array}{l}0.99 \\
0.89\end{array}$ & $\begin{array}{l}3.45 \\
6.80\end{array}$ & $\begin{array}{l}0.380 \\
0.403\end{array}$ & $\begin{array}{l}0.054 \\
0.053\end{array}$ & $\mid \begin{array}{l}1.19 \\
0.48\end{array}$ & $\left|\begin{array}{l}0.6 \mathrm{I} \\
0.62\end{array}\right|$ & $\begin{array}{r}0.58 \\
-0.14\end{array}$ \\
\hline
\end{tabular}

Table I shows a gradual increase in the percentage of clay from I 5.3 percent in the first six inches of soil to 22.7 percent in the fourth foot, with a corresponding decrease in the amount of very fine sand. This means that there is a transition from a very fine sandy loam in the upper foot of soil to a clay loam in the region of the second to the fourth foot. A break comes at 4 feet, below which level the texture is again that of a very fine sandy loam. The hygroscopic coefficients and moisture equivalents consistently follow these differences in texture.

The clay content even in the hardpan is not outstandingly high. Many soils of easy tilth in more humid regions have much more clay. Hence the 
climatic factors, especially precipitation, on the Great Plains must be considered.

The normal annual precipitation at Burlington is 17 inches, of which by far the greater part falls during the spring and summer months. However, as is shown in Table 3 and confirmed elsewhere (Shantz, I9II), the water that actually penetrates deeper than I.5 to 2 feet falls in the spring, when evaporation is relatively low and crops (now rooted entirely in shallow levels) are not making heavy demands upon the supply. During this period (April to June) the water may penetrate into the hardpan layer to some extent. When this occurs the hardpan softens and disappears as far as the wetting proceeds. Later, when drought conditions prevail, it dries out again and hardens as before. Table 3 indicates the water-content in excess of the hygroscopic coefficient (approximately the available water-cf. Weaver, I920, p. 28) at the different levels for the growing seasons of 1920 and I92 I, both seasons having a total precipitation somewhat above the normal. While many of the figures show a percentage below the hygroscopic coefficient, this is probably due in the surface soils to direct evaporation and elsewhere to local variations in the soil samples in regard to their relative amounts of sand and clay. Computations were made on the basis of the hygroscopic coefficient of a single carefully selected composite sample from each of the several levels ( $c f$. Shantz, I9I I, p. 30).

TABLE 3. Water-content in excess of hygroscopic coefficient, Burlington, Colorado

\begin{tabular}{|c|c|c|c|c|c|c|c|c|c|c|}
\hline \multirow{2}{*}{ Date } & \multicolumn{2}{|c|}{0.0 to $0.5 \mathrm{ft}$. } & \multicolumn{2}{|c|}{0.5 to $1.0 \mathrm{ft}$. } & \multicolumn{2}{|c|}{ I to $2 \mathrm{ft}$. } & \multicolumn{2}{|c|}{2 to $3 \mathrm{ft}$. } & \multicolumn{2}{|c|}{3 to $4 \mathrm{ft}$. } \\
\hline & Sod & ield & Sod & ield & Sod & d & Sod & Field & Sod & Field \\
\hline I & & & & & & & & & & \\
\hline Apr. I 5 . & I 6.7 & 22.0 & I3.7 & I0.5 & II.I & 0.5 & 4.9 & -O.I & I. 8 & -0.4 \\
\hline & 2.3 & & & 6.4 & $7 \cdot 3$ & 3.I & 6.9 & 5.1 & 2.9 & -0.6 \\
\hline $\mathrm{J} \mathrm{u}$ & -1.8 & & $-0 . I$ & 3.8 & 2 & & & & & \\
\hline $\mathrm{J} \mathrm{u}$ & $7 \cdot 4$ & 6.4 & 2.5 & I.7 & I. 8 & 0.8 & I.4 & 2.7 & -2.5 & I. 6 \\
\hline $\mathrm{Ju}$ & -1.6 & -2.0 & -0.5 & -I.I & 0.0 & 0.0 & & & & \\
\hline Jul & -2.9 & -2.0 & -1.3 & -0.4 & -2.2 & $-\mathrm{I} .4$ & & 0.7 & & I. 8 \\
\hline Jul & -0.7 & 0.5 & -2.7 & -2.6 & -1.7 & -2.8 & 2.5 & -0.5 & -0.6 & 2.0 \\
\hline Aug. 5 . & 4.6 & 4.4 & 2.7 & 0.0 & -2.7 & I.3 & -0.6 & 0.0 & -3.1 & -1.9 \\
\hline I9. . & -3.1 & & -3.1 & & -0.5 & & & $\ldots$ & & \\
\hline Aug. $24 \ldots$. & -0.8 & -0.7 & -2.1 & -0.9 & -1.9 & -2.2 & -0.6 & 2.5 & $-\mathrm{I} .4$ & $-\mathrm{I} .8$ \\
\hline April 30. . & 9.6 & I I. 2 & 10.7 & 9.7 & 8.6 & 8.8 & 0.0 & 2.4 & I & 0.9 \\
\hline M & 6.4 & 6.6 & 5 & $7 \cdot 4$ & 4.7 & 3 & -0.7 & -0.7 & -2.2 & 0.2 \\
\hline IO. & 10.3 & 2.7 & 0.0 & I. 9 & 0.7 & 0.3 & -0.5 & -0.4 & -0.6 & -0.2 \\
\hline 30. & -2.6 & -2.6 & $-\mathrm{I} .6$ & $-\mathrm{I} .9$ & -1.5 & $-2 . I$ & $-\mathbf{I} .0$ & $-\mathbf{I} .0$ & -1.3 & $-\mathrm{I} .3$ \\
\hline I 7 . & -1.0 & $\ldots \ldots$ & -1.0 & & -3.6 & & & & & 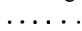 \\
\hline 24 . & -3.5 & $\ldots \ldots$ & -2.2 & & -3.4 & $\ldots \ldots$ & $-\mathbf{I} .8$ & & -0.4 & \\
\hline & 2.0 & $\ldots \ldots$ & -0.7 & & $-2 . \mathrm{I}$ & & -0.3 & & $-I .0$ & \\
\hline I 7 . & I6.9 & & I I. 7 & & -2.4 & & -2.0 & & $\ldots$ & \\
\hline Aug. 29. & -0.3 & & 0.5 & & $-2 . \mathrm{I}$ & & -0.4 & & $-I .0$ & \\
\hline
\end{tabular}

From these data it is clear that the hardpan layer in general and its base in particular marked the limit of maximum penetration of rainfall. Shantz's 
findings (I9II) and also those of Briggs and Shantz (I9I2) corroborate this conclusion.

Under these conditions of water penetration, the concentration of colloidal clay and carbonates in the subsoil is sufficient to give rise to a hardpan-i.e., a much more compact stratum of soil relative to that above or below it-upon its becoming so completely dried out. The cementing power of ultra-clay when the material is dry is very striking, quite exceeding that of Portland cement, as has been demonstrated by Moore et al. (I92I). Jensen (I9I8) found that "plowsole" in the citrus groves of southern California contained a higher percentage of inorganic colloid suspension than the soil mulch, and usually a higher percentage than the subsoil. Table 2 shows that the water of hydration in the soils at Burlington, obtained by subtracting the organic matter from the volatile matter, is highest in the hardpan layer and falls off remarkably below it.

\section{Root Distribution of Native Plants}

Root distribution of native vegetation has been determined at several widely separated stations in Colorado. Not only the dominant grasses, but numerous subdominants, including non-grassy species, have been examined. About 5 miles northwest of Sterling, Colorado, the following species were studied: buffalo grass Bulbilis dactyloides, grama Bouteloua gracilis, wire grass Aristida purpurea, Texas crab grass Schedonnardus paniculatus, brownweed Gutierrezia sarothrae, and a cactus Opuntia polyacantha. The open mats of buffalo and grama grass indicate a low water-content. Much of the I 5 inches of annual precipitation is lost by run-off from the very compact finesandy loam, which is underlaid at a depth of 2 feet with a well-defined hardpan about 8 inches thick.

Bulbilis dactyloides, a dominant of the short-grass plains and a species with a very wide distribution, has been excavated in many places. While soil type and water relations have some effect upon the extent of the lateral distribution of rootlets in the surface soil, this being much more pronounced in drier soils, the depth of penetration remains quite uniform, about 5 to 7 feet. At Sterling the fine, well-branched, fibrous roots penetrated the hardpan and extended into a very dry layer of gravel and small pebbles mixed with sand, many roots reaching a depth of over 5.5 feet.

The roots of Bouteloua gracilis are similar in fineness and degree of branching to those of Bulbilis and, like those of the latter, they spread widely, I.5 feet or more on all sides of the plant, in dry soils. They normally reach a working depth (i.e., a level to which many roots penetrate and to which depth considerable absorption occurs) of about 3 feet and have a maximum penetration of at least 4 feet. At Sterling the soil was quite filled with the roots of this dominant to a depth of 2.5 feet; they were fairly abundant to 3.2 feet, while some extended a foot deeper. 
Aristida purpurea characterizes large areas of grassland throughout the Great Plains, especially where the soil is slightly sandy or where overgrazing or other disturbance has given it a foothold in competition with buffalo and grama. Typically the coarse fibrous roots spread laterally 5 to 8 inches, and, unlike the preceding short-grasses, branch but little in the surface 4 inches of

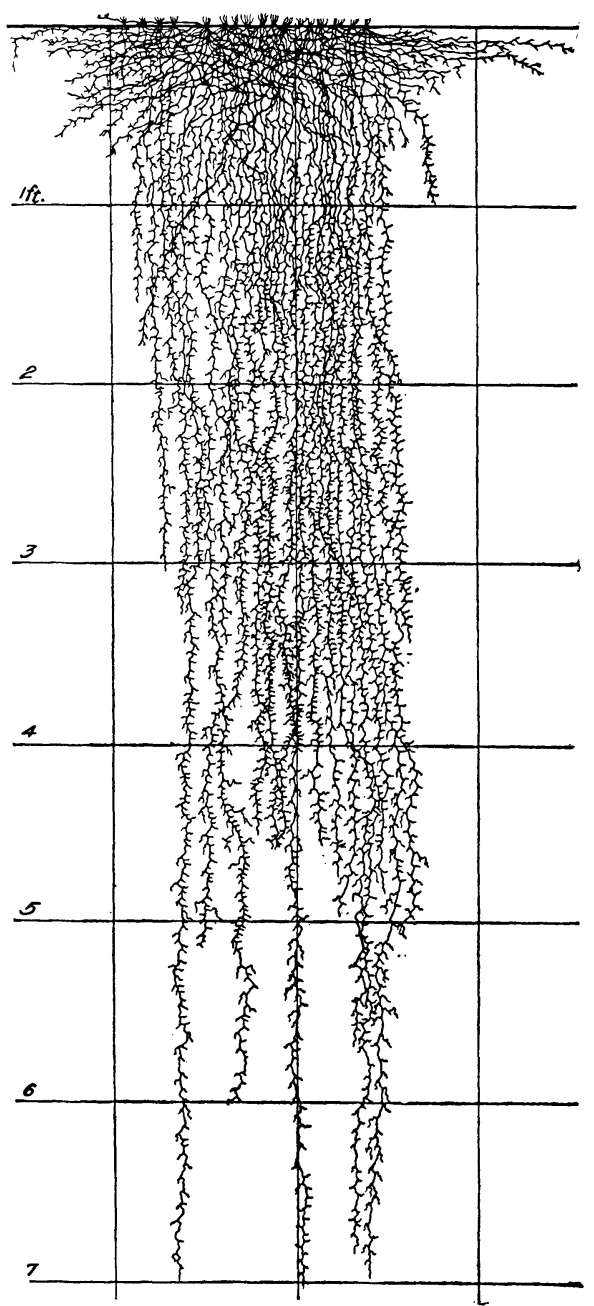

FIG. I. Root system of buffalo grass, Bulbilis dactyloides.

soil. However, its working depth is about 2.5 feet and the maximum penetration 3 or 4 feet. In the sod at Sterling the bunches, which were rather small, had a lateral spread of roots of 7 inches, but none penetrated more than 0.3 foot into the hardpan.

The annual or sometimes short-lived perennial, Schedonnardus panicu- 
latus, is nearly always present in small numbers in the short-grass sod. It is an excellent indicator of overgrazing or other disturbance. The root habit is much like that of Aristida, but the depth of penetration is only about two feet.

Gutierrezia sarothrae is a perennial half-shrub which forms societies throughout the plains region. Rather small specimens occurred at Sterling. The woody tap roots were 4 to $8 \mathrm{~mm}$. in diameter. These were furnished with abundant laterals, many of which spread 0.5 to $\mathrm{I} .5$ feet in the surface 3 or 4 inches of soil before ending or turning downward. Most of the branches ended in the third or fourth foot of soil and none were traced to a greater depth than 5 feet. In more moist areas greater lateral spread and deeper penetration ( 6.5 feet) have been determined.

Opuntia polyacantha is a plant of common occurrence in short-grass lands and frequently of great abundance in over-grazed areas. Like many other cacti, the root system consists of two rather distinct parts-a few vertically descending roots and many shallow ones which spread widely in the surface 3 or 4 inches of soil. The four or five roots of each plant which descended vertically were only fairly well branched and did not extend beyond 2 feet in depth. The profusely branched shallow roots ( 44 to 24 per plant) spread laterally to distances of I to 5.5 feet.

Thus among the six species examined at this station four had a working level below or well within the hardpan layer, while two penetrated into it slightly or not at all, since their root systems are normally developed in the first two feet of soil.

At Yuma, Colorado, the soil consists of a brown fine-sandy loam, which is very hard when dry and breaks out in lumps, showing more or less of a columnar structure. It is underlaid, where the roots were excavated, at a depth of 2.8 feet by a well-formed hardpan which was 8 to Io inches thick. Below this layer the loess was mellow and at 7 feet in depth of an ashy consistency. The roots of buffalo grass were found to have a working depth of 5 feet and a maximum penetration of 7 feet. As indicated in figure $I$, the roots show no difference in branching habit either above, in, or below the hardpan layer.

Psoralea tenuiflora, a widely distributed species and one of the most important legumes of the Great Plains, was also excavated at the same time. This species is characterized by a taproot and numerous large, widely spreading laterals, especially in the deeper soil. Frequently the taproot fenetrates to I or 2 feet before branching, thus very little, if any, absorption occurs in the surface soil. Maximum depths of penetration of 8 to over I2 feet have been determined. The root habit is rather constant whether the plant grows in dry or moist situations. The specimen excavated at Yuma is shown in figure 2, where it may be seen that the bulk of the root system lies below the 
hardpan level. The tap was traced to a depth of 9 feet, at which point it was still $4 \mathrm{~mm}$. in diameter and running rather vertically downward.

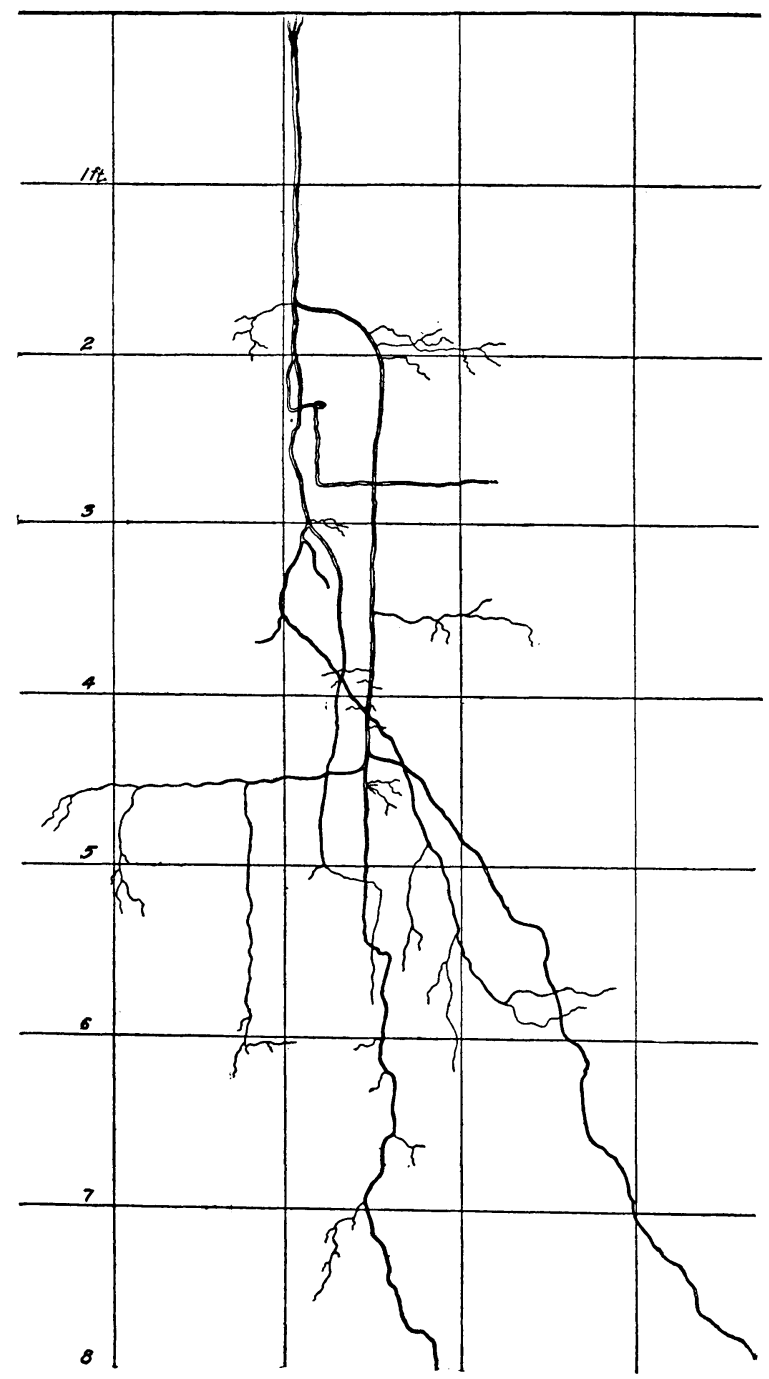

FIG. 2. Root system of psoralea, Psoralea tenuiflora.

Eight miles south of Limon, Colorado, in an area where the compact finesandy loam was underlaid at a depth of 2.5 feet with a hardpan, the roots of Ealbilis, Psoralea, the milk pink Lygodesmia juncea, and certain other native species were found extending far below the hardpan, some to a depth of over 7 feet.

Numerous studies on root development have been made in the vicinity of 
Burlington, Colorado. In an area 7 miles northeast of this town trenches were dug in the closed mat of buffalo grass and grama sod. The soil was similar to that already described (pp. 237-238) and was underlaid by hardpan at a depth varying from 1.9 to 2.3 feet. In thickness the hardpan varied from 0.5 to 1.6 feet. The soil was fairly moist to 3.5 feet, below which, though very mellow, it was powdery dry. Here the roots of buffalo grass were

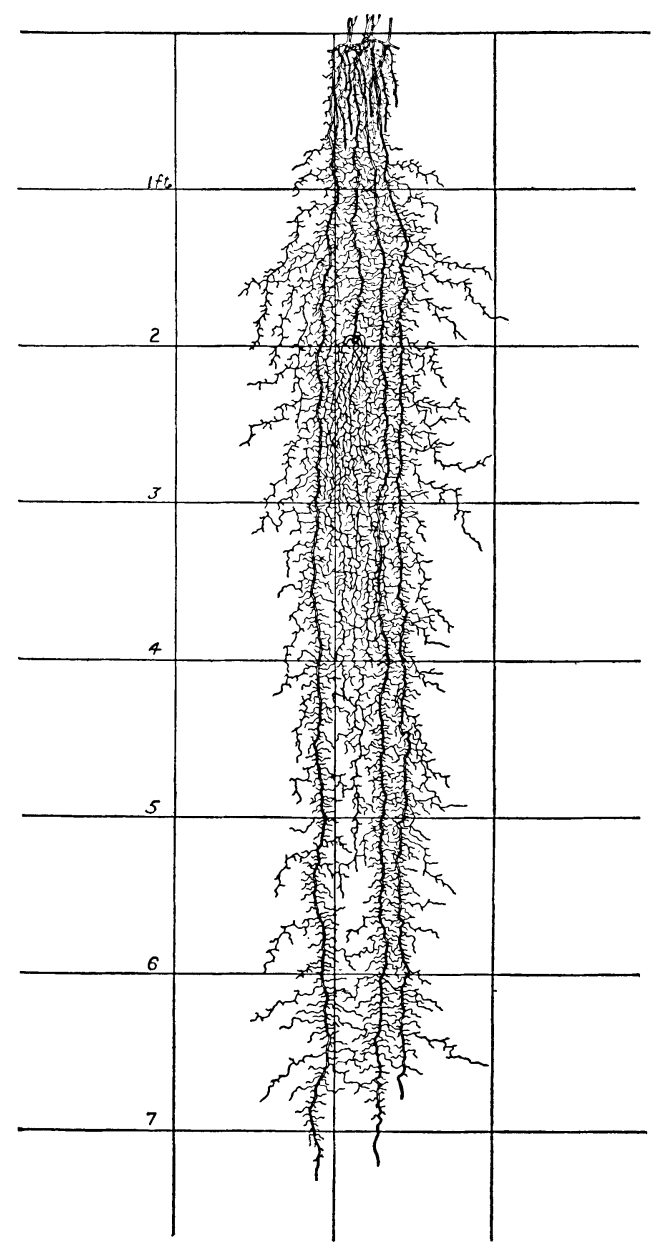

FIG. 3. Root system of tall panic grass, Panicum virgatum.

found in abundance at 4.3 feet, and some reached depths of 6 feet. The wire-grass clumps were rather small and no roots reached depths greater than 2.8 feet. Those of Lygodesmia were found to penetrate as deeply as those of Bulbilis.

Further studies in Burlington showed a similar distribution of the roots 
of the native vegetation. Blocks of sod about a foot square and 8 inches thick obtained from the prairie at Lincoln, Nebraska, were planted in the short-grass sod during 1920 and I921 (Clements and Weaver, I920). Among these were tall panic grass, Panicum virgatum, and bluestem, Andropogon furcatus. By July of the second season the former, aided by a fairly moist soil due to the collection of some run-off water, had reached a depth of over 7 feet-about its usual penetration-and was much more profoundly branched than normally (fig. 3). The roots of the bluestem, at least during the first season, were limited in growth by the depth of the moist soil, which did not extend beyond the hardpan (Table 3 ).

\section{The Root Distribution of Crop Plants}

Crop plants, including both winter and spring wheat, rye, barley, oats, alfalfa, and sweet clover, have been repeatedly excavated and examined, not only at many stations in the Great Plains, but in the prairie region eastward. This affords an excellent basis for comparison and shows the effect of limited water-content upon root development. To avoid undue length these data are presented in tabular form, with the preliminary statement that root extent was in every instance in close agreement with depths of available watercontent. In a few cases where the soil was moist to considerable depths, the roots responded by extending their area until they had reached rather normal development, as expressed in the more humid regions of eastern Nebraska. The working depth and maximum penetration of the roots under these more favorable conditions are appended in Table 4 for purposes of comparison.

A survey of Table 4 reveals at once an unusual root penetration of all of the cereals at the station 7 miles northeast of Burlington. These plants were excavated on a rather level area on June 29, 1919, at which time studies were also made in two different areas in the adjoining grassland. Here, at depths of 1.9 to 2.3 feet, the lighter-colored but not very firm-textured hardpan was encountered. It was 0.5 to 1.6 feet thick. The soil was fairly moist to 3.5 feet, below which it was powdery. However, in the fields of wheat, oats, and barley the soil was moist to more than 7 feet in depth, being easily molded into firm lumps with only slight pressure of the hand. An examination of the rainfall records shows that an excess of nearly 3 inches over the normal precipitation had occurred the preceding December and 4.3 inches in June. Moreover, the actual precipitation, owing to its very local nature on the Great Plains, may have been more here than where recorded at Burlington. Runoff from the grassland sod was probably much greater than from the cultivated areas, also snow may have added to the actual precipitation by forming drifts near the fences in the fields not far from the places of root excavation. Here, as in a field at Colby, Kansas, where seepage water from an irrigation reservoir had thoroughly moistened the hardpan, this layer, so conspicuous when dry, had been modified to such an extent that one could not distinguish it by casual examination from the soil above or below. 
TABLE 4. Depth and thickness of hardpan and distribution of the roots of crop plants All data are given in feet

\begin{tabular}{|c|c|c|c|c|c|c|c|}
\hline \multirow[b]{2}{*}{ Crop } & \multirow[b]{2}{*}{ Station } & \multirow[b]{2}{*}{ 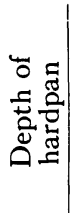 } & \multirow{2}{*}{ 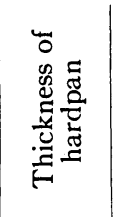 } & \multirow{2}{*}{ 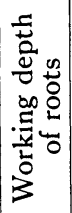 } & \multirow{2}{*}{ 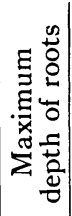 } & \multicolumn{2}{|c|}{$\begin{array}{c}\text { Eastern } \\
\text { Nebraska }\end{array}$} \\
\hline & & & & & & | & 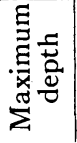 \\
\hline Winter rye. . & $\begin{array}{l}\text { Yuma, Colo. } \\
\text { Flagler, Colo. } \\
\text { Burlington, Colo. }{ }^{1} \\
\text { Limon, Colo. } \\
\text { Colby, Kans. }\end{array}$ & $\begin{array}{l}3.6 \\
2.5 \\
2.1^{2} \\
2.5 \\
2.3\end{array}$ & $\begin{array}{c}0.8 \\
0.7-0.9 \\
0.5-1.6 \\
0.8 \\
2.1\end{array}$ & $\begin{array}{l}2.2 \\
2.3 \\
4.3 \\
2.0 \\
3.0\end{array}$ & $\begin{array}{l}2.8 \\
2.8 \\
6.0 \\
2.0 \\
3.6\end{array}$ & 4.0 & $5 \cdot 3$ \\
\hline Winter wheat (Turkey red) & $\begin{array}{l}\text { Yuma, Colo. } \\
\text { Sterling, Colo. } \\
\text { Flagler, Colo. } \\
\text { Burlington, Colo. }{ }^{1} \\
\text { Colby, Kans. } \\
\text { Limon, Colo. }\end{array}$ & \begin{tabular}{l|}
3.6 \\
2.8 \\
1.3 \\
$2.1^{2}$ \\
2.1 \\
2.5
\end{tabular} & $\begin{array}{c}0.9 \\
0.8 \\
0.8 \\
0.5^{-1.6} \\
0.9 \\
0.8\end{array}$ & $\begin{array}{l}2 . \mathrm{I} \\
2.7 \\
1.4 \\
3.8 \\
2.0 \\
2.0\end{array}$ & $\begin{array}{l}2.3 \\
2.8 \\
1.5 \\
5.4 \\
2.3 \\
2.8\end{array}$ & 3.8 & $5 \cdot 4$ \\
\hline $\begin{array}{l}\text { Spring wheat (mostly Mar- } \\
\text { quis) } \ldots \ldots \ldots \ldots \ldots\end{array}$ & $\begin{array}{l}\text { Flagler, Colo. } \\
\text { Limon, Colo. } \\
\text { Burlington, Colo. }{ }^{3} \\
\text { Burlington, Colo. }^{4}\end{array}$ & $\begin{array}{l}2.3 \\
2.5 \\
2.7 \\
2.6\end{array}$ & $\begin{array}{c}0.7-0.9 \\
0.8 \\
\mathrm{I} .3 \\
\mathrm{I} .2\end{array}$ & $\begin{array}{l}2.5 \\
2.0 \\
2.7 \\
2.2\end{array}$ & $\begin{array}{l}2.8 \\
2.0 \\
2.7 \\
2.5\end{array}$ & 3.0 & $4 \cdot 5$ \\
\hline $\begin{array}{l}\text { Oats (mostly white Kher- } \\
\text { son) } \ldots \ldots \ldots \ldots \ldots \ldots\end{array}$ & $\begin{array}{l}\text { Flagler, Colo. } \\
\text { Colby, Kans. } \\
\text { Burlington, Colo. }{ }^{1} \\
\text { Burlington, Colo. }^{3} \\
\text { Burlington, Colo. }\end{array}$ & \begin{tabular}{l|} 
I.6 \\
1.9 \\
$2 . \mathrm{I}^{2}$ \\
2.7 \\
2.6
\end{tabular} & \begin{tabular}{|c|}
0.9 \\
0.7 \\
$0.5^{-1.6}$ \\
1.3 \\
1.2
\end{tabular} & $\begin{array}{l}1.7 \\
2.5 \\
4.0 \\
2.7 \\
2.2\end{array}$ & $\begin{array}{l}1.9 \\
3.0 \\
5 \cdot 3 \\
2.7 \\
2.5\end{array}$ & 3.4 & $4 \cdot 4$ \\
\hline Barley (Manchuria). . & $\begin{array}{l}\text { Burlington, Colo. }{ }^{1} \\
\text { Burlington, Colo. } \\
\text { Burlington, Colo. }\end{array}$ & \begin{tabular}{l|}
$2.1^{2}$ \\
2.9 \\
2.6
\end{tabular} & $\begin{array}{l}0.5^{-I} .6 \\
\text { I.2 } \\
\text { I.2 }\end{array}$ & $\begin{array}{l}4.2 \\
2.5 \\
2.0\end{array}$ & $\begin{array}{l}5.7 \\
2.9 \\
2.5\end{array}$ & 3.1 & 5.0 \\
\hline Biennial white sweet clover $^{5}$ & Burlington, Colo. & 2.7 & 1.3 & 2.8 & 2.8 & 5 & 6.5 \\
\hline Alfalfa ${ }^{6}$ & Burlington, Colo. & 2.2 & I. 8 & 2.0 & 2.3 & 8 & $8-10$ \\
\hline
\end{tabular}

1 Data from fields about 7 miles northeast of Burlington.

${ }^{2}$ No hardpan evident, depth judged from that in adjoining grassland.

3 Station in Burlington, 1920.

4 Station in Burlington, I921.

5 Examined in August of first season's growth.

6 Examined in July of second season's growth.

Omitting this unusual condition, an examination of the table shows that in only 6 fields did the working depth of the roots of either the cereals or legumes extend below the upper surface of the hardpan. Three of these were near Flagler, two at Colby, and one in the field of sweet clover at Burlington. Data from these root studies, which extended over a period of 3 years, and years which were unusually favorable for crop growth, indicate conclusively 
that the supply of available water, which is the controlling factor to root extent in this region, occurs normally above the hardpan level. While a few of the more deeply penetrating roots extended from 0.1 to 0.6 foot into the hardpan layer, it more frequently happened that maximum root depth was

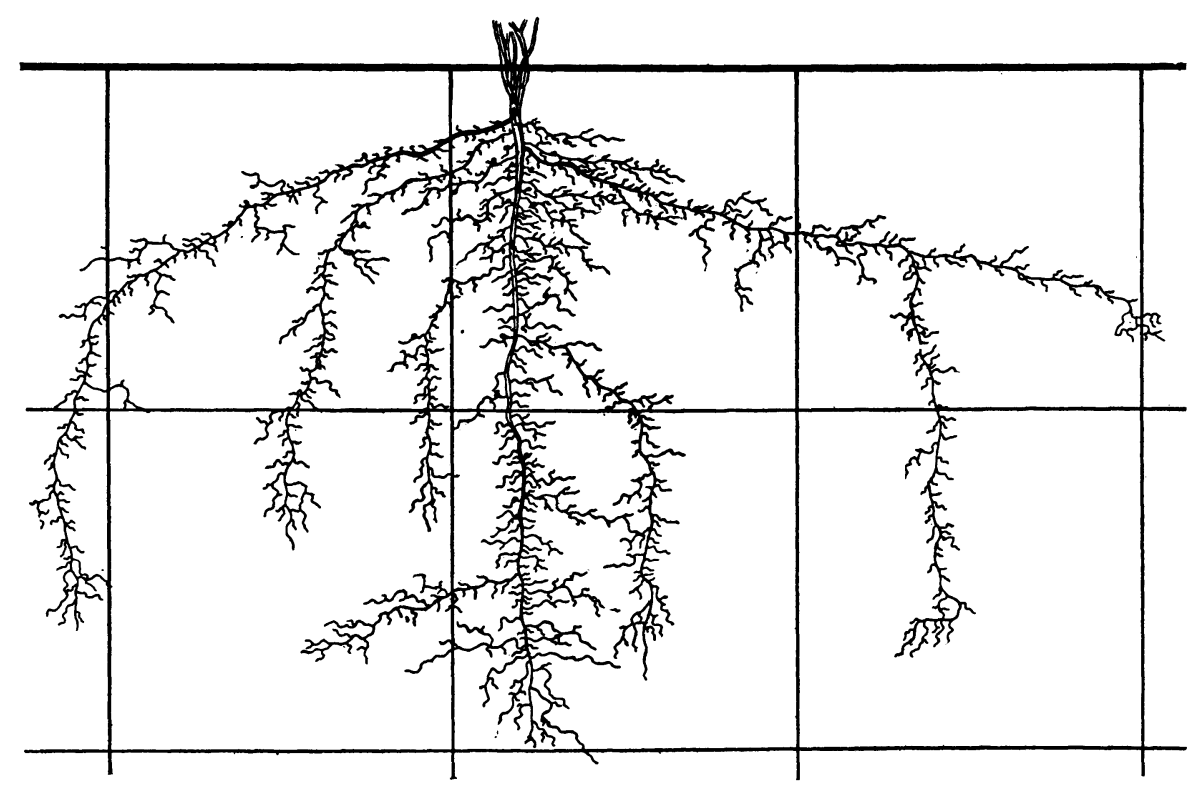

FIG. 4. Root system of Alfalfa during second year of growth.

either less or coincided with the depth of the latter. In only one case (rye at Colby) did the roots penetrate throughout the hardpan. Even the normally deep alfalfa was confined to approximately the surface 2 feet of soil, and its usually strong, poorly branched taproot underwent such profound modifications as scarcely to be recognizable (fig. 4).

The length of time during which the field had been broken from the native grassland had little effect upon root depth. This varied from one or two years (rye at Yuma) to over 20 years (rye at Flagler). Moreover, the effect exerted upon the root habit by the amount and placement of the available soil water much more than overbalanced any varietal differences in root habit as determined under more favorable conditions for growth (cf. fig. 5).

The habit of the roots of many of the native species of penetrating into the hardpan and often several feet below it, while growth of underground parts of crop plants is usually delimited by it, should be considered. The most logical explanation is that the relatively short-lived crop plants meet only occasionally (as exemplified at Burlington) with efficient precipitation of such amount that the hardpan (which in itself is no barrier to root penetration) is sufficiently moist to induce root growth. On the other hand, the long- 
lived native species (buffalo grass, psoralea, etc.) at some time during their life must experience periods when not only the hardpan, but also the soil below, is sufficiently moist to induce root growth. How long these roots, once

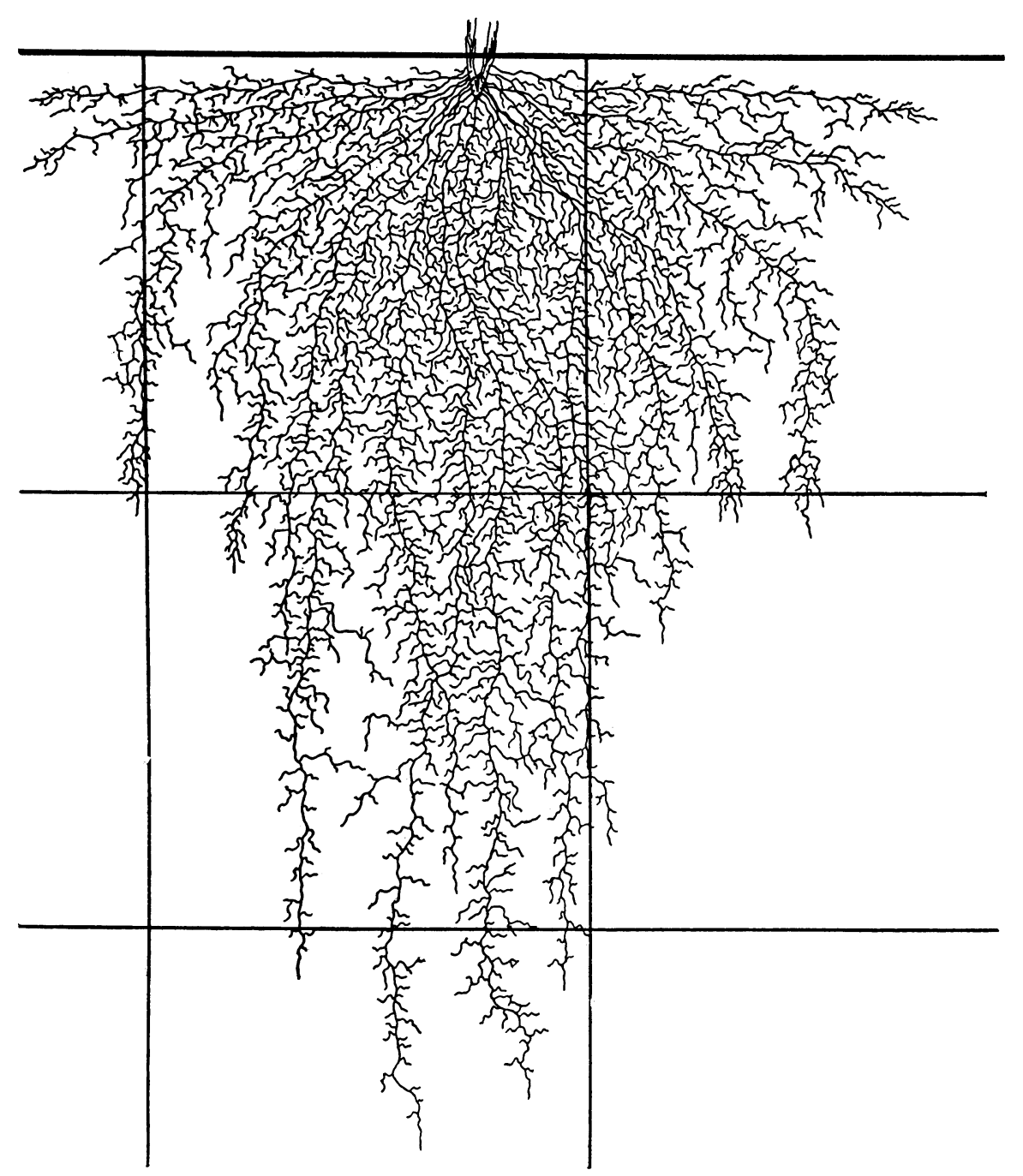

FIG. 5. Root system of mature White Kherson oats.

formed, remain alive and active is yet to be determined. The ability of these native species to grow in soil too dry for good development of ordinary mesophytic crop plants may also play a part. 


\section{SUMMARY}

A so-called hardpan exists in the soils over much of the Great Plains region at depths of 1.4 to 3 feet. It varies in thickness from 8 inches to over I.5 feet. In some localities it appears to be due largely or entirely to the calcareous nature of the soil. In others it is clearly caused by the concentration and cementing effect of colloidal clay aided in part by the carbonates. Water-content determinations show that the hardpan occurs at approximately the normal depth of water penetration. When moist it disappears, but reappears again upon the desiccation of the soil.

Available water is the controlling factor of root extent in this region and occurs normally only above the hardpan. Thus the hardpan in general delimits the depth of penetration of crop plants, but under exceptional moisture conditions they may extend their roots 5 or 6 feet deep. Many of the native species penetrate into the hardpan regularly, not only extending their roots through it, but often several feet beyond. No modifications in root habit were apparent in the hardpan layer. Since roots will not grow far into dry soil, the logical explanation of the fact is that at some time during the life of these perennials water must penetrate through the hardpan. How long these deeper roots remain alive after the subsoil is again desiccated is undetermined.

Alway, F. J., and C. O. Rost.

\section{LITERATURE CITED}

'I6 The Loess Soils of the Nebraska Portion of the Transition Region. Soil Science I: 405 .

Alway, F. J., G. R. McDole, and R. S. Trumbull.

'I9 Relation of Minimum Moisture Content of Subsoil of Prairies to Hygroscopic Coefficient. Bot. Gaz. 67: 185.

Briggs, L. J., and H. L. Shantz.

'12 The Wilting Coefficient for Different Plants and its Indirect Determination. U. S. Dept. Agr., Bur. Pl. Ind. Bull. 200.

Clements, F. E., and J. E. Weaver.

'20 Transplant Quadrats and Areas. Carnegie Inst. Wash. Year Book 19: 355. Jensen, C. E.

'I8 Relation of Inorganic Soil Colloids to Plowsole in Citrus Groves in Southern California. Journ. Agr. Res. 15: 505.

Moore, C. J., W. H. Fry, and H. E. Middleton.

'2I Methods for Determining the Amount of Colloidal Material in Soils.

Shantz, H. L. Journ. Ind. \& Eng. Chem. 13: 527.

'II Natural Vegetation as an Indicator of the Capabilities of Land for Crop Production in the Great Plains Area. U. S. Dept. Agr., Bur. Pl. Ind. Bull. 201.

Weaver, J. E.

'Ig The Ecological Relations of Roots. Carnegie Inst. Wash. Pub. No. 286.

'20 Root Development in the Grassland Formation. Carnegie Inst. Wash. Pub. No. 292.

Weaver, J. E., F. C. Jean, and J. W. Crist.

'22 Development and Activities of Roots of Crop Plants. Carnegie Inst. Wash. Pub. No. 316. 